\title{
超音波断層法による前立腺診断
}

\begin{tabular}{|c|c|c|c|}
\hline \multirow{3}{*}{$\begin{array}{c}\text { 東北大学医学部泌尿器科学教室 } \\
\text { (主任:宾戸仙太郎教授) }\end{array}$} & 渡 & \multicolumn{2}{|c|}{ 辺 } \\
\hline & 加 & 藤 & 弘 \\
\hline & 加 & 藤 & 哲 \\
\hline & 森 & 田 & 昌 \\
\hline 東北大学抗酸菌病研究所内科 & 田 & 中 & 元 \\
\hline （主任：岡捨己教授） & 寺 & 沢 & 良 \\
\hline
\end{tabular}

\section{DIAGNOSTIC APPLICATION OF THE ULTRASONOTOMOGRAPHY FOR THE PROSTATE.}

\author{
Hiroki Watanabe, Hiroaki Kato, Tetsuro Kato and Masayoshi Morita \\ From the Department of Urology, Tohoku University School of Medicine, Sendai \\ (Director: Prof。 S. Shishito) \\ Motonao Tanaka and Yoshio Terasawa \\ From the Research Institute for Tuberculosis and Leprosy, Tohoku University, Sendai
}

(Director: Prof. S. Oka)

A prostatic ultrasonogram was clearly visualized with transrectal PPI-scanning using a specially prepared concave transducer. Results of the measurement on the size of the prostate agreed almost with that on the specimen. Prostatic hypertrophy and prostatic calculi were successfully diagnosed with this procedure. A considerable improvement on the ultrasonic diagnosis of the prostate would be expected from application of the concave transducer.

\section{I 緒 言}

私達は凹面振動子を用いて直腸内から PPI (Plan-position-indication) 走查を行なう超音波断層法によつて， 從来の報告よりかなり明瞭な前立腺および精鼠の超音波 断層像を得ることに成功し, その臨床的意義の大きいこ とを認めたので，2，3 の症例に蛙ける結果とともに報 告する。

\section{II 方 法}

共振周波数 $5 \mathrm{MC}$, 直径 $10 \mathrm{~mm}$, 曲率半径 $60 \mathrm{~mm}$ の円形凹 面チタン酸バリウム振動子を装着した。直径 $11 \mathrm{~mm}$, 長さ 450mmの体腔内 PPI 走查用探触子を用いた ${ }^{1)}$ 。直腸壁 の損傷を防ぐため, との 先端部を直径約 $12 \mathrm{~mm}$, 厚さ約 $0.5 \mathrm{~mm}$ の゚リエチレン管で覆い,さらに水浸法で走查を 行なうため，ラテックスゴムカフを装着した。接触剤と してキシロカインゼリーを叙布したのち，この探触子を 硉石位に固定した患者の肛門より直腸内へ插入し、ゴム
カフ内に約 $20^{\circ} \mathrm{C}$ 脱気水 $10 \sim 20 \mathrm{cc}$ 注入して直腸壁へ密 着せしめ，手動によつていわゆる極近接水浸法”による PPI 走查を行なつた。探触子の PPI 走査運動と投射さ れた超音波ビームの方向とをブラウン管上で一致させる ため，変換器としてレン゙ルバーを使用した。

超音波送信器調度は発振周波数を $5 \mathrm{MC}$, くり返し周 波数を $1 \mathrm{KC}$ とし，パルス巾は振動子端子間において 1.2ないし $1.3 \mu \mathrm{S}$ として使用した。受信器の増巾度は 100ないし $110 \mathrm{~dB}$ としたが, 近距離エコ一の飽和を防 ぐため追込みの深さを約一 $10 \mathrm{dE}$ とし，水中距潍に換算 して約 $5 \mathrm{~mm}$ の距離から， $15 \mu \mathrm{S}$ の 時定数で受信器感度が 回復するような function をるつ $\mathrm{STC}^{3)}$ を加味した。 なおこの装置の詳細については，すでに海老名ら゙が報 告している。插入図に撤ける二重同心円は，振動子より それぞれ $50 \mathrm{~mm}$ 抢よび $100 \mathrm{~mm}$ の距離における標識信号であ る。 


\section{III 症例および結果}

症例 1 . 石○庄○, 18才, 自衛隊員.

臨床診断 : 左遊走腎. 前立腺正常.

前立腺触診所見：クルミ大，弾性硬，表面平滑，左右 対称で, 圧痛を認めず。精囊は両側とも軟で, 硬結・腫 脹を認めず。

超音波診断所見：膀脱内に $150 \mathrm{cc}$ の水をカテーテルに て注入した。肛門より $11 \mathrm{~cm}$ 点で, 直腸壁とほぼ接して 方形の膀胼壁に起因すると考兄られるェュー（以下膀羘 エコーと呼ぶ）像が描出され，その中央にカテーテルの エュー像が明瞭に認められた，さらに前方には数層にわ たる腹筋と腹壁のエコーが認められた．直腸前側方に は，右はほぼ円形，左は半月形の精囊に起因するとみら れるェコー像（以下精囊エコーと呼ぶ）があり，その一 部は直腸前方へと向つていた (第 1 戝). 膀胱エューは 肛門より $14 \mathrm{~cm}$ 点から $9 \mathrm{~cm}$ 点の範囲で得られた .

肛門より $8 \mathrm{~cm}$ ない $6 \mathrm{~cm}$ の間では, 前立腺に起因する エュー像（以下前立腺エコーと呼ぶ）が得られた。肛門 より $7 \mathrm{~cm}$ の点では, 前立腺は横約 $2.5 \mathrm{~cm}$, 絽約 $2 \mathrm{~cm}$ の 角形に近いェュー像として描出され，その後部には細か い点状の大きさ均一なェューが無数にみられ，中央には カテーテルによるエュー像が認められた．前立腺の側方

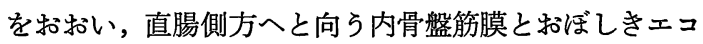
一も明瞭であつた．直腸後方には尾骨によると思われる エュー像が得られた（第 2 図）.

症例 2 . 山○義 $\bigcirc, 29$ 才, 大学助手.

臨床診断: 左尿管結石症. 前立腺正常.

前立腺触診所見：クルミ大, 弾性硬, 表面平滑, 左右 対称で圧痛を認めず．精襄は触知せず．

超音波診断所見：肛門より $13 \mathrm{~cm}$ から $9 \mathrm{~cm}$ の深さで膀脱

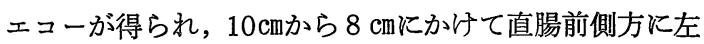
右対称な半月状の精䨗エコーが認められた. 前立腺エコ 一は $8 \mathrm{~cm}$ から $5 \mathrm{~cm}$ にかけて得られた。

肛門より $5 \mathrm{~cm}$ の点では, 前立腺ェューは横約 $3 \mathrm{~cm}$, 縦 約 $1.5 \mathrm{~cm}$ で, その後半部には前例と同様細かい均一な点 状エコーが多数散在した（第 3 図）。 カテーテルは挿入 していない.

症例 3 . 及○吉○郎，67才，会社員。

臨床診断：前立腺肥大症.

前立腺触診所見 : 鵎卵大, 弾性やや軟, 表面顆粒状,

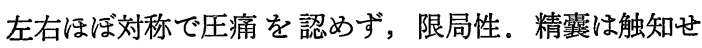
ず.

レ線䛦断所見 : 尿道膀胱造影で前立腺部尿道は延長し
（約 $5 \mathrm{~cm}$ ), 鞘状拡張を示し，その下端前右方に僅かな石 灰化像をみた。精管精譱造影では, 精鼠は水平型で右が 左に比べやや拡張するも，両側とも破壊像はなく，射精 管は両側とも欠損せず，射精管間隙は僅かに開大してい た。

手術所見 : 恥骨後前立腺被膜内摘出術施行. 外科的被 膜との癒着はみられなかつた．摘出標本 は横 $4 \mathrm{~cm}$ ，縦 $2.5 \mathrm{~cm}$, 高さ $3 \mathrm{~cm}, 17 \mathrm{~g} て ゙$, 下端に僅かな石灰沈着があ り，組織学的には腺腪様過形成であつた。

超音波診断所見：肛門より $12 \mathrm{~cm}$ から $10 \mathrm{~cm}$ にかけて膀 胱, $10 \mathrm{~cm}$ で両側精霝, $9 \mathrm{~cm}$ から $4.5 \mathrm{~cm}$ にかけて前立腺に よるエコーが得られた．精霅ェューは右が左に比べ拡張 していたが，周辺は平滑であつた．前立腺エコーは横約 $4 \mathrm{~cm}$, 縦約 $2.5 \mathrm{~cm}$ で, 前述の細かい均一な点状エューを 欠き, 周縁拉よび左右両葉間に連続した粗な点状ェュー をみるのみであつた，前立腺下端の尿道附近に，尿道膀 胱造影に和ける石化像と一致する密集した明膫なェュー 群を認めた (第 4 図).

症例 4 . 高○与○治, 70才, 無職。

臨床診断：前立腺肥大症兼結石症.

前立腺触診所見: 超クルミ大,一般に硬, 表面平滑, 左右ほぼ対称で圧痛あり，周囲との移行はやや不明瞭。

精霅は触知せず。

レ線診断所見 : 尿道膀胱造影飞て前立腺部尿道は軽い 鞘状拡張を示し，その周囲全体にわたり多数の結石を認

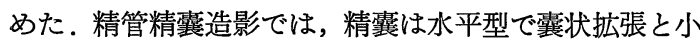
腔の消失が著るしく，右側は強く拡張していたが，左側 はかなり菱縮していた。左射精管像は欠損していた。

手術所見: 経恥骨的前立腺全摘出術施行. 前立腺を両 側精孁とともに一塊として摘出した。前立腺は横 4.7 $\mathrm{cm}$, 縦 $3.5 \mathrm{~cm}$, 高さ約 $3 \mathrm{~cm}, 55 \mathrm{~g}$ （精襄を含む）で，割 面には多数の小結石 および結節がみられた（第 $5 ， 6$ 図).

超音波診断所見：肛門より $10 \mathrm{~cm}$ の深さで，膀胱および 両側精囊エコーが得られた．左精潢はやや小さく，右は 拡張しており，その周囲はいずれも凹凸不平であつた。

肚門より 9 ないし $6 \mathrm{~cm}$ にかけて前立腺エコーが得られ た.エコー像からみた前立腺の大きさは横約 $4.5 \mathrm{~cm}$, 縦 約 $3.5 \mathrm{~cm}$ で摘出標本とほとんど完全に一致していた．前 立腺後半部拉よび一部右側部にかけて, 前述の均一な点 状エコーよりやや大かつ密集した不規則な群状エコーが 認められたが，これは摘出標本に淤ける硬い結節を形成 する部分とほぼ一致していた。 また前立腺各部にわた 
第 1 図 症例 1 肛門より $11 \mathrm{~cm}$. 正常膀胱および精囊のエコー像.
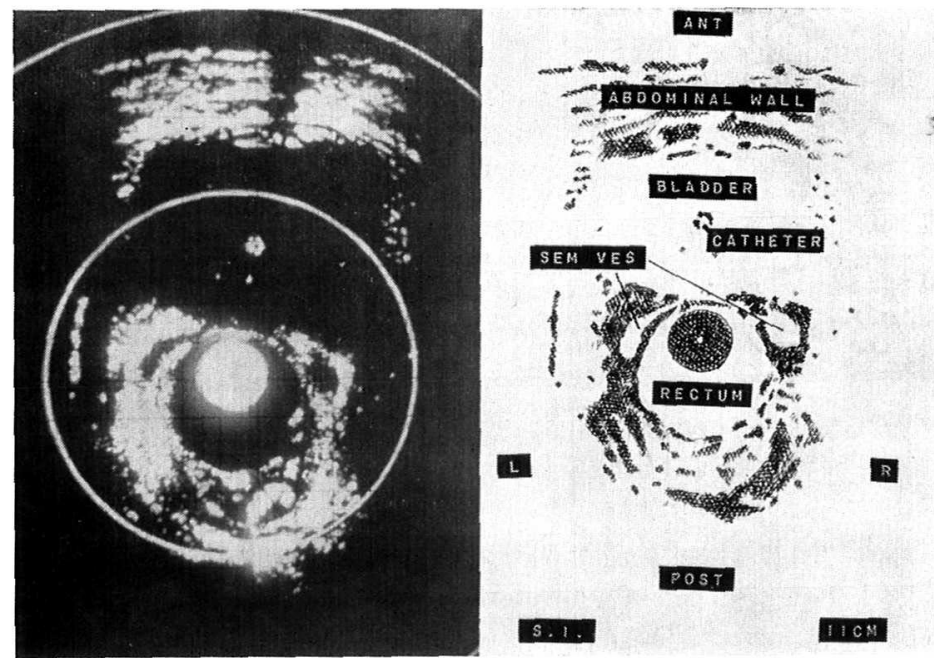

第 2 図同例 肛門より $7 \mathrm{~cm}$. 正常前立腺のエコー像.
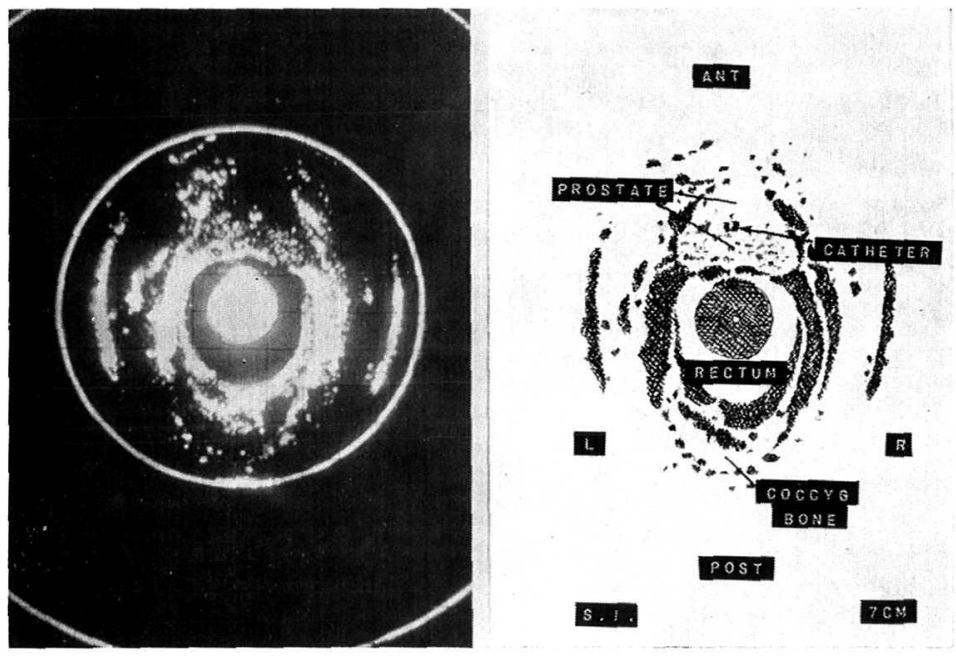

第 3 図症例 2 肚門より $5 \mathrm{~cm}$. 正常前立腺のエコー像.
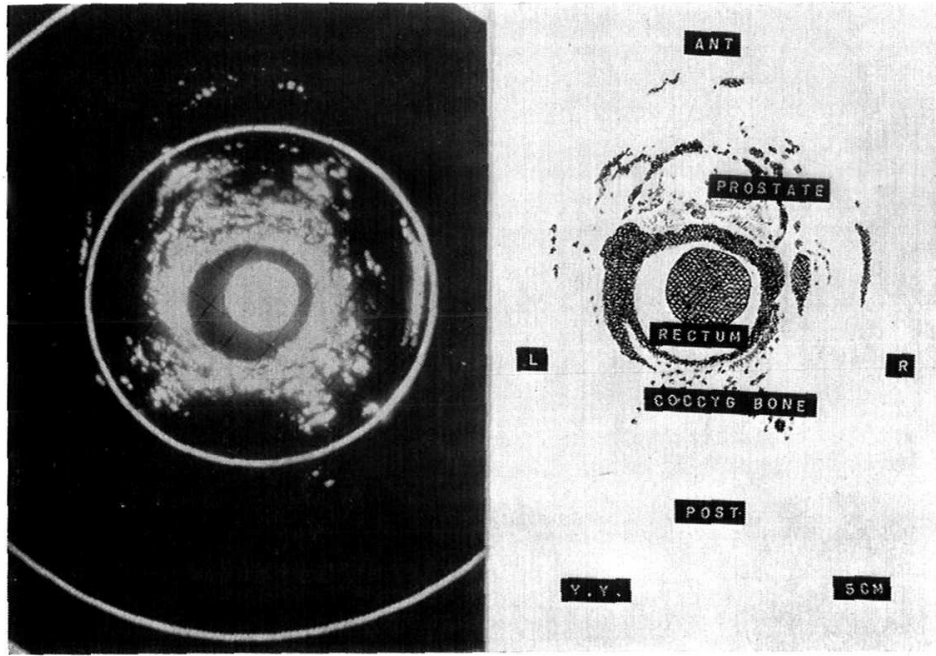
第 4 図 症例 3 肛門より $4.5 \mathrm{~cm}$. 前立腺肥大症の前立腺下端部に括々るエコー像. 左右両葉の分離执よび尿道周囲の石灰化像をみる。

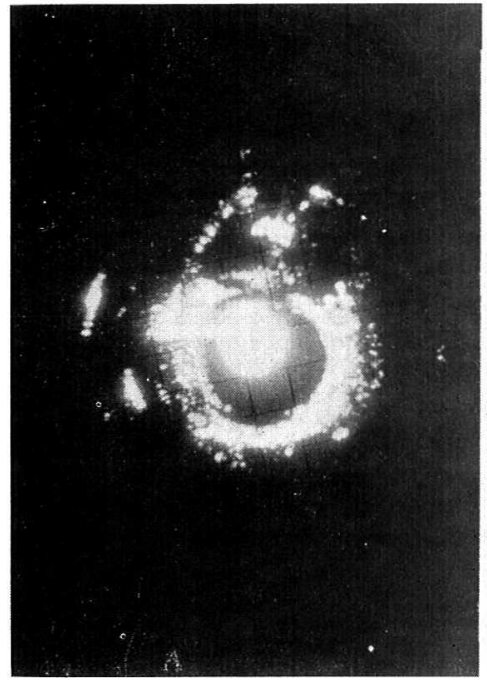

第 5 図症例 4 前立腺肥大症兼結石症. 肛門上り $7 \mathrm{~cm}$ 附近の前立腺エコー像とその摘出標 本割面および組織像.
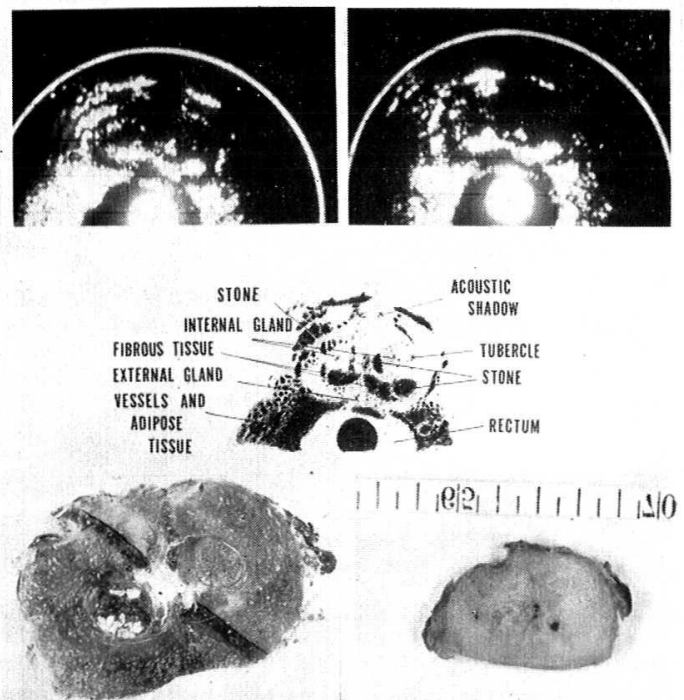

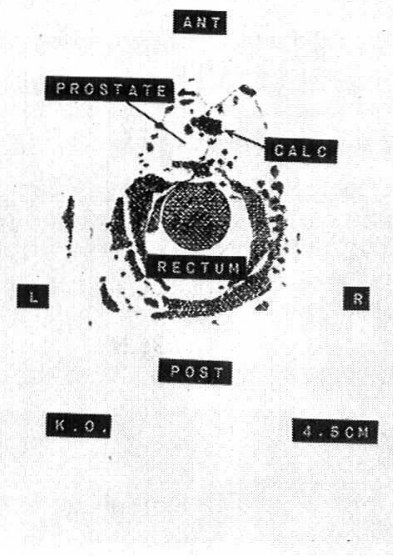

第 6 図同例 左上, 右上, 左下, 右下の順に, 前 立腺上部から下部にかけてのエコー像お よびその部分に相当する摘出標本割面.
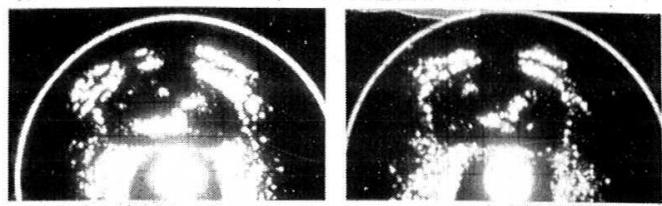

C91111111100
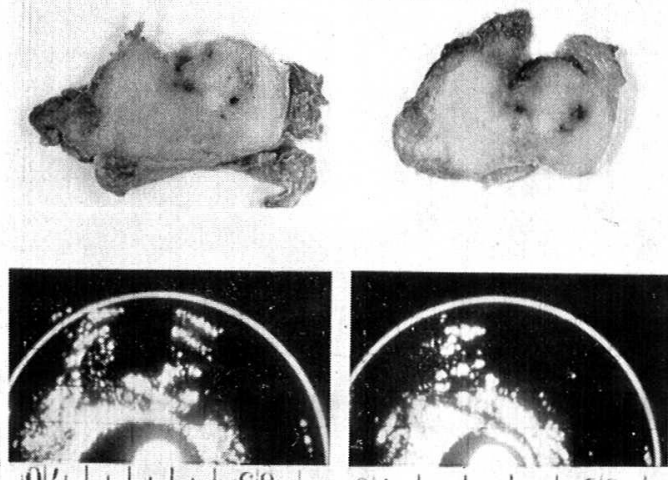

$0|2| 1|1| 1 \mid 99$
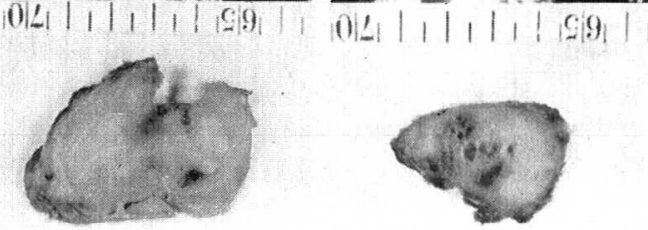
り，さらに一層強い点状エコーがみられたが，これは結 石の存在部に相当していた。これらの所見は摘出標本の それぞれの割面と対比して，第 $5 ， 6$ 図に示した。

\section{IV 考察}

前立腺の巨視的診断法としては, 現在尿道膀胱造影。 精管精䨝造影などの間接的に前立腺陰影を示すにすぎな い2，3のレ線診断法が実用化されているのみで，前立 腺そのものの形態を摘出することは，多くの試みがなさ れながらるな社未解決のままであつた。これは前立腺が 軟性組織なのでレ線透過性は周囲組織とあまり 異なら ずまた周囲へ何らかの造影剤を注入することも解剖学 的にきわめて困難なためと思われる。これに対し超音波 は, 軟性組織あるいは実質性臓器の透過性がよく, 僅か な密度差のある組織境界面（音響インピーダンスの異な る境界面）で反射波を生ずるという物理的性質をるつて いる。そのため骨盤内臟器疾患を超音波パルス反射法に より診断しようとする試みは，早くからなされてきた。

前立腺についても，まず直腸内からAスコープ法によ り矢のエコーを検知する方法が, 主として本邦の泌尿器 科学者を中心に試みられた。すなわら高橋・大内 ${ }^{526)}$ 特 よび後藤・西 ${ }^{788)}$ は，直腸内へ挿入可能な振動子を用い て得た Aスコープ像に执いて, 前立腺肥大症, 癌和よび 結石症に，それぞれ特有なエコーパターンがみられるこ とを指摘した。 また Pell ${ }^{99}$ も同様な方法で, 前立腺癌 が正常とまつたく異なるェコーを示すと述べている．大 内ら ${ }^{10)}$ によればこのAスコープ方式による前立腺診断適 中率は非常に高く，日常検査の 1 つとして充分な価値を 有するとのことである。

しかしながらAスコープ方式は, 超音波が伝播する 1 次元方向のみのエコーの大きさを表示するものであるか ら，対象物までの距離とそのェコーの大きさを知るには よいが，生体のごとくそれぞれ音響インピーダンスを異 にする組織境界面が複雑にいりこんだものを対象とする 場合には，その分布状態を示し得ないため，得られたエ コーパターンの判定が非常に難かしく，再現性にもそし い.またAスコープによるエューパターンの上で癌と肥 大症に相違があるといつても，その差はかなり微妙なる のであつて，判定に苦しむ場合も少なくない，私達は PPI 走查施行之同時にAスコープによる反射波図形る 観察しているが，これのみで組織性状を云々するのは相 当困難と思われた。前立腺診断のために超音波反射法を 応用する本来の目的は, 前立腺の形態の変化，すなわち 単にその大きさのみならず内部構造の変化をも非観血的
に把握するところにあると考兄られる。この目的のため にはA スュープ表示は好都合な方法とはいい得ない。そ こでェューの大きさを定量的に測定することは困難であ るが，エコーを生ずる組織境界面の分布状態やその距離 を，直観的な断面図として表示しらる超音波断層法が大 きな意義を有することになる，超音波断層法にはPPI走 查のほかにBスコープ表示あるいは Compound 走査が あるが，私達は前立腺の水平断面が示される PPI走查を まず応用した。その他の走査法については現在検討中で ある。

前立腺の PPI走查についても高橋 。大内 ${ }^{5) 6}$ の報告が ある. しかしその断層像かり判断すると必らずしも実用 的なものとはいい難く，像の精度の点にかなりの問題が あると思われた。一般に PPI 方式・Bスュープ方式な ぞを含む超音波断層法において得られる像の良否，すな わち解像度の良否は, 主として距離分解能・方位分解能 扣よび指示器の指示性能の 3 つの因子によつて左右され る. ある均一媒質中に存在する小反射体を走查して得ら れるェューをブラウン管上に表示した場合, 距離分解能 が悪いときは，実際には点状の物体でも音波伝播方向 （あるいは超音波ビーム方向）に縦に長い直線状のエコ 一像として示され, また方位分解能が悪いときは, 走查 方向（あるいは方位方向）に横に長い直線状あるいは円 孤状のエュ一像として示される。両者の分解能が悪けれ ば，その物体からのエコー像は実際よりはるかに大きい 円形の像となるわけである。したがつて前立腺のような 小さい物体の内部を仔細に検討するためには，この両者 の分解能を相当向上させねばならない。

距離分解能を決定するのは主として超音波パルスの巾 であり，方位分解能を決定するのは主として振動子より 放射される超音波ビームの巾である.すなわち超音波バ

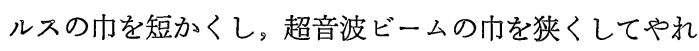

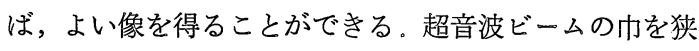
くするためには，音響レンズ・反射鏡なども利用される が，なるべく寸法の小さいことを要求される体腔内振動 子の場合は，凹面振動子を用いるのが有利である.田中 。菊地 ${ }^{11)}$ によれば，凹面振動子を反射法に用いる場合 (振動子半径) ${ }^{2} /$ (曲率半径) $\times$ (波長) $\leq 4$ とすると ビームが音波伝播方向に細長くなり，ビーム巾が狭くな つて方位分解能を向上させ得るが，この值が極端に小さ いと平面振動子の特性に近くなつて, 凹面効果が失われ てしまらという.ここでは前立腺診断用振動子として, $5 \mathrm{MC}$, 直径 $10 \mathrm{~mm}$, 曲率半径 $60 \mathrm{~mm}$ の凹面振動子を使用し 
て良好な効果を得ることができた．この場合上述の值は 1.4 となる。

一方距離分解能に影響する超音波パルスの巾は，前述 のごとく短かいほどよいのであるが，そのためには生体 内での超音波の透過性を考慮して, 可能なかぎり高い周 波数の超音波を用いる必要がある。ここでは振動子端子 間の測定で 1.2 ないし $1.3 \mu \mathrm{S}$ の送信 パルス巾を使用 し， $5 \mathrm{MC}$ の周波数を選んだが，その結果距離分解能 およびェコー検出可能距離範囲ともにほぼ満足な成績が 得られた。

直腸内から PPI 走查を行なつて前立腺の超音波断層 像を得ようとする際のもう 1 つの問題点として, 近距離 投射の影響を考慮しなければならない，振動子の大きさ が超音波波長より大きい場合には，振動子から比較的近 い距離にある音場内では，投射された音波が干渉しあつ て強弱の縞を作り複雑な干渉帯を形成する．この近距離 干渉帯の範囲内にある物体からのエコーは，ブラウン管 上では実物とかなり違つた像になる可能性があるから， この範囲はなるべく狭める必要がある．凹面振動子は同 一寸法の平面振動子に比べ, 近距離干渉帯の及ぶ距離を 短縮できる゙11ので有利である。

また同一反射率をもつ反射体でも，近距離にある反射 体からのエコーは遠距離のものに比べ非常に大きく, 両 者を同一感度で受信すると近距離からのエコーが飽和の 現象を起し，解像度を低下させることになる。この点 を改善するため，私達は方法の章で述べたごとき STC (Sensitivity time control. 受信器感度を時間経過とと もに人為的に変化せしめ, 近距離エコーに対する感度を 下げてそのェコーの大きさを遠距離エコーの大きさと同 程度にし，断層像全体を注济均一な輝度の像にするため の機構）を用いた。 この場合凹面振動子を使用すると， その音場分布の上ですでに近距離での音圧が低くなつて いる ${ }^{11}$ から， STC の効果はさらによく現われてくる。 これらの方法によつて図に示したごとく近距離のェュー 像は良好となり，充分解読しらるものとなつた。

なお極近接水浸法で PPI 走査を行ならため, 接触子 先端部にポリエチレン管とラテックスゴムカフとを装着 したが，多重反射を生ずることもなく，ぬた著明な超音 波減衰をも来さず, 直腸壁の防護, 振動子の接着, PPI 走查時の回転抵抗の軽減および探触子先端部の固定に役 立ち，良好な効果をあげることができた。

さてこれらの方法によつて得られた臓器エコーについ て，少ない症例ではあるが多少の検討を加える。
膀脱エコーは肛門より 14 なし $9 \mathrm{~cm}$ の距離で得られ た.膀脂内に約 $100 \mathrm{cc}$ の水を注入するとその像はより明 膫となり，膀脱内にあるネラトンカテーーテルはいずれ の症例に怙いてもきわめて明確なエコーとして認められ た. 膀脱側壁もよく描き出され, 膀胱壁の形態的変化も かなりの程度に吟味が可能であり, 将来膀脱腫瘍の浸潤 度判定などにも超音波診断を応用できる可能性がある。 肛門より11ないし $8 \mathrm{~cm}$ の深さで, 膀脂エコーとともに精 覀エコーが得られた。精䨳は内腔の㚈半円状または 三日月状の像をなし, その側壁のエューはかなりの確実 性をもつていた。

さらに振動子を抜いてくると, 膀胱底部から生じたと 思われる均質なエコーが現われ，肛門より 9 ないし $5 \mathrm{~cm}$ の附近で前立腺エコーが認められた。この深さは正常例 にあつてはやや浅く, 前立腺肥大症々例にあつてはやや 深い. 私達の経験では, 直腸内のどこの位置から走査し ても, 同じ振動子の位置で膀胱と前立腺とのエコーを同 時に得ることは不可能であつた。これは直腸走行に対す る膀胱和よび前立腺の解剖学的位置関係によるものと考 兄られた。な和振動子の位置を表示するために，私達は 肛門よりの深さを用いたが，肛門はかなりの可動性を有 するために絶対的な基準としては適当でない，この点に 関しては将来何らかの指標を設定する必要があると思わ れた。

正常前立腺内部では例外なく, 大きさ均一な細かい点 状エコーを無数に認めた：このエコーはかなり特徴的 で，前立腺上部と下部では多少その分布を異にし，前立 腺肥大症や結石症にあつても, 組織性状が正常に近いと 思われる部分では同様に出現した。これが腺内のいかな る組織から生ずるかはなお不明であるが，以上の所見よ りみて，このエューはいわば正常前立腺エューと称して も差支えないように思われる。

前立腺肥大症拈よび結石症にあつては，この正常前立 腺エコーの出現が少ないか,あるいはこれを欠いている. 手術により摘出した実物標本の割面と超音波断層像を対 比してみると，組織性状の硬い結節をなす部分に一致し て,やや大さい密集した不規則な斑点状エコーが認めら れた．組織性状がさらに硬いと考兄られる部分ではその 振動子に面する部分に強いエコーがみられ，それより遠 距離では，音響陰影が現われた。結石からはさらに強い 明瞭なエコーが得られた。そして結石ェコーの大きさは 結石の大きさに比例しており, 他の部分のエューとの判 別も可能であつた。 
以上の所見は，凹面振動子を用いた前立腺超音波断層 写真法が, 現段階の技術でもかなりの組織解像力を有し ていることを示した結果と考兄られる。またェュー像の 上から計測した前立腺の大きさは，手術摘出標本のそれ とほぼ完全に一致した。このことは，他に前立腺の大き さを測定する適当な検査法がない現在，それだけでも有 力な前立腺診断法といらことができる.

私達は数例の前立腺癌症例に対しても同様な超音波断 層法を適用し，いくつかの興味ある所見を得たが，その 像は相当複雑であり, 結論を出すにはな技多くの検討が 必要である. 前立腺癌の早期発見や他疾患との鑑別は, 前立腺超音波診断の大きな目的の 1 つであると思われる ので，少ない症例に将ける結果をもとにして軽々に論じ ることは許されない，私達は今後さらにこの方面に関す る研究を一層進めたいと考えている.

いずれにせよ，前立腺の超音波診断はすでに実用段階 に入りつつある. 近い将来この検査法が，前立腺疾患の 判定に必要不可欠なるのとなることは, 疑いない事実で あると思われる。

\section{$\mathbf{V}$ 結 語}

PPI 走查方式による経直腸前立腺超音波断層法に凹面 振動子を応用し，明瞭なエコー像を得ることに成功した ので，2，3 の症例を供覧するとともに若干の考察を加 えた. 凹面振動子の使用はこの検査法にとつてはなはだ 有効である．超音波断層法による前立腺の大きさ計測は
非常に正確であり，また前立腺内部の組織構造の变化も かなりよく表示し得るものであつた。今後の電子技術の 発達にともない，前立腺超音波診断法は大いに発展する 可能性があると思われる.

御指導・御校閲いたら゙いた宾戸仙太郎教授・岡捨己教 授,ならびに超音波機器の製作に御協力いたぶいた日本 無線医理学研究所に深謝する.

\section{交 献}

1) Ebina, T. et al.: Sci. Rep. Res. Inst. Tohoku Univ.-C, 12, 199, 1965.

2）田中元直ら：第 9 回日超医論交集，11，1966。

3）田中元直ら：第11回日超医論交集, $27,1967$.

4) 海老名敏明ら：抗研誌, 17, 300, 1965.

5) Takahashi, H. \& Ouchi, T.: Jap. Med. Ultrasonics, p. 7, Oct. 1963.

6) Takahashi, H. \& Ouchi, T.: Jap. Med. Ultrasonics, p. 35, May 1964.

7) Gotoh, K. \& Nishi, M.: 泌尿紀要, 11, 87, 1965.

8) Gotoh, K. \& Nishi, M.: 泌尿紀要, 13, 18, $1 \mathrm{C} 67$.

9) Pell, R.L.: Ultrasonics, 2, 87, 1964.

10) Ouchi, T. et al.: Jap. Med. Ultasonics, 3, $15,1965$.

11）田中元直 - 菊池喜充: 医用電子と生体工学, 5, $352,1967$.

（昭和 43 年 2 月 1 日受付, 特別掲載） 